УДК: 719:72, 711.56, 726.596, 726.5.04

ББК: 63.4, 85.11

A43

DOI:10.18688/aa166-2-11

Halûk Çetinkaya

\title{
To Excavate or not? Case of Discovery of an Early Christian Baptistery and Church at Ulpiana, Kosovo
}

One of the best methods to obtain information about the past is to excavate a site or a settlement using scientific methods. Ancient sources may provide vital information only if they are unbiased. Writers of these sources are generally geographers, pilgrims, merchants, captains etc. A certain event may be interesting for one, but it can be totally neglected by others. For this reason archaeologists and art historians have to approach them with caution.

As any operation may cause unknown and unexpected side effects, the same applies to excavations as well. Frescoes or mosaics, which were conserved under ground for several centuries, once exposed to the air might become irreversibly damaged. One of the best known examples of such damage is the case of Çatalhöyük. During the excavations of the 1960s, upon discovering wall paintings, the head of excavation team decided not to dig any further since there was no availiable technology to preserve them. Alas, it is not the case most of the time. Excavators with different expectations may or can not sacrifice. The dilemma in this case is to decide whether to continue excavating or not. This article intends to set an example for Early Christian archaeology in this context.

Subject of the article, ancient city of Ulpiana is $12 \mathrm{~km}$ from the city centre of Pristina, capital city of Kosovo, and $2 \mathrm{~km}$ from the nearby town Gračanica.

Upon the arrival of Romans, this region became a new province named Moesia after Moesi's. This newly established province was divided into two - Moesia Superior and Moesia Inferior prior to 86 A.D. [26, p. 68]. Ulpiana was within the boundaries of Moesia Superior. Later, this region was named Dardania and it became a Roman province. For this incident reigns of Aurelian, Diocletian and Justinian I were suggested [20, pp. 196-197]. But most favoured view is the reign of Diocletian [35, pp. 1386-1387].

The location of the ancient city of Ulpiana was unknown, but the consensus was that it is the modern township of Lipjan. The site of Ulpiana was discovered in the first quarter of the $20^{\text {th }}$ century [2, p. 272]. Archaeological excavations commenced in 1953 continued with intervals in the following decades. Basing on pottery analysis, it has been proved that Ulpiana was settled in the $1^{\text {st }}$ century A.D. by Romans, although the name of the settlement remained unknown [11, p. 31]. The site was believed to be settled prior to the Roman arrival. During first years of archaeological excavations it was claimed to be a Prehistoric settlement [3, p. 376]. There were some small objects found on the site, which led us to such conclusion. 
But those objects are to be approached with caution, since they could have been carried away by nature or brought in by human activities. One of the most important factors for the site of Ulpiana are the mines which were exploited as early as Prehistoric period. The region was well known for its silver and gold mines during Roman period [14, p. 128]. During the excavations of the 1980s, the discovery of urns from the late Bronze age (Brinica culture, 1350-950 B.C.) indicated the earliest settlements of Ulpiana [7, p. 67].

There is no information about the boundaries of the city. Close to the northern cemetery, at its south, some houses dating $3^{\text {rd }}-4^{\text {th }}$ centuries were unearthed [12, p. 267]. This could be taken as an indication of the city limits. Since no city walls were found, it was suggested that it was a settlement without city walls [20, p. 97]. The city walls were constructed in the $4^{\text {th }}$ century and constantly maintained until the $6^{\text {th }}$ [31, pp. 63-65]. Approximately 100 metres east of city, a few small portions of another wall were discovered. This was taken as a proof of a new settlement. According to this theory, the city of Ulpiana shrank and instead of continuing to settle at its original place a new site, which is smaller and at the east of the former one, was established [10, p. 44]. Existence of these walls was known as early as 1926 [2, pp. 269-272]. They were considered to be part of a military installation. To confirm this theory, several soundings were made which proved that these were defensive walls with towers probably belonging to a military campus [1, p. 86].

The first record of the name of Ulpiana in ancient sources dates to the beginning of the $2^{\text {nd }}$ century A.D. in Ptolemaios. It was mentioned along with Scupi, Naissus and Arribantium [29, III.5]. Ulpiana was founded by the emperor Marcus Ulpius Traianus (98-117 A.D.) and named after him. It is generally considered that Ulpiana was given the status of municipum either at its foundation [25, p. 164] or soon afterwards, in the $2^{\text {nd }}$ century A.D. [28, no. 1686]. Until the $5^{\text {th }}$ century, there was no record of Ulpiana in any sources. Most likely, it was damaged by the invasions of Huns [32, p. 241] and Goths in the middle of the $5^{\text {th }}$ century A.D. [27, pp. 285-286].

Although it was not included in the list of 24 cities [6] damaged by the earthquake of 517/518, Ulpiana also must have been affected. After that earthquake, the city walls, much damaged and idle, were brought down by Justinian I (527-565). There were no city walls before the $4^{\text {th }}$ century, and upon its construction, a constant maintenance was needed until their reconstruction in the $6^{\text {th }}$ century [31, pp. 63-65]. Justinian I beatufied the city and refounded it under the name of Iustiniana Secunda [9, IV.1.28-30]. It was suggested that after the invasion of the Slavs in 618 Ulpiana was uninhabited [ 31, pp. 57-58; 11, pp. 7-9]. This date has to be questioned since there is evidence of a continuing usage of some buildings such as northern church.

When the city fell into ruins, the materials were reused by the locals for construction activities. It is most visible through the monastic church of Gračanica, where epitaphs were used in lower parts of the walls.

Archaeological excavations began in 1953 but yielded enormous results until 1959. Several sites were dug out including three cemeteries, parts of the city walls and the northern gate, a large church near the gate, another church near the northern cemetery, a stylobate of a Roman temple, and walls of a Roman military camp east of the city. A Roman villa along with the rest of the city walls and towers were discovered during the excavations of the 1980s and 1990s. In the 2000s, French [17, pp. 449-458] and German teams [1, pp. 82-88] together with Kosovar Albanian historians and archaeologists performed some geo-physical surveys and excavations at different locations. 
Christianity began to flourish in the Balkans as early as the $1^{\text {st }}$ century A.D. Its spread was most probably caused by soldiers. Ulpiana was no exception. The first mention of christians in Ulpiana is by means of martyrdom of twin brothers, Sts. Florus and Laurus. The brothers were from Constantinople and worked on pagan temple construction in Ulpiana. Upon performing a medical miracle, their christian identity was deciphred and they were dumped into a very deep well and martyred in the $2^{\text {nd }}$ century A.D. [8, p. 345]. Their skulls were kept in Constantinople at least until the $14^{\text {th }}-15^{\text {th }}$ centuries [23, pp. $\left.42,152,162,186,290,293\right]$. This information was provided by Russian pilgrims who visited Constantinople. It is interesting to note that cult of Sts. Florus and Laurus spread very rapidly afterwards in Russia. They were known to be healers of horses [18, p. 209]

Clergy members from Dardania and Macedonia were mentioned in the sources starting the $4^{\text {th }}$ century. For example, bishops Machedonius and Paul who participated in the council of Serdica in 343 and synod of Constantinople of 553 respectively [15, p. 41; 36, pp. 156-163]. Another important name from Ulpiana is Gregentius. According to tradition, Gregentius of Ulpiana was sent to Ethiopia and Yemen during the reign of Justin (518-527) to ease problems among different christian groups [27, LVI.285-286].

Ulpiana, most probably was a bishopric before the invasions of Goths in the second half of the $4^{\text {th }}$ century [27, LVI.285-286].

Until the year 545, Ulpiana was known as the Metropolis of Dardania. After that date, in order to ease the rivalry between Serdica and Iustiniana Prima, this title was given to the latter [33, pp. 279-280].

Christianity must have been accepted widely in Ulpiana. Numerous christian buildings might be taken as proof of it. There were at least four Early Christian structures in the city based on our current knowledge. Two of them, namely the church near Northern gate and the church on the Northern cemetery where discovered and excavated between 1956-1959 [34, p. 326]. Basing on the presumable connection with the historical martyrs of the city, the first church was named the "church of martyrs". It is a tripartite basilical church with narthex. According to the excavators, the church had five construction phases. The oldest phase had floor mosaics [4, p. 325]. That church was dated to the $6^{\text {th }}$ century [34, p. 326]. Although there was a record about the floor mosaics in the church, neither photos, nor drawings of it have been published.

Outside the church, parallel to its southern wall, there were three column bases were found in situ. Although it did not attract much attention of the excavators, it was an important find. This clearly indicates a parekklesion. The existence of parekklesia has been known from the $4^{\text {th }}-5^{\text {th }}$ centuries. It can be found on several plans [21, p. 1587]. Parekklesia, especially during the middle Byzantine period (843-1204), became widespread. It was found in pairs, mostly parallel to southern and northern walls of the structure terminating with an apse [5, p. 245]. Due to location of column bases, it is clear that parekklesion, at least on the southern side, was there for as long as the southern wall of the church existed. Since these kinds of parekklesia were common in the middle Byzantine period, it may be suggested that parekklesion was added long after church had been built. If that was the case, the church and the city appeared much later than it would be suggested; maybe as late as the $10^{\text {th }}$ century, when Dardania was believed to be Slavicized [24, p. 190]. 
The church on the Northern cemetery was built on top of graves which were dated to the $4^{\text {th }}$ century, whereas the church itself was dated to the $6^{\text {th }}[37, \mathrm{p} .326]$. That was a church ending with one apse on the east. There are two chambers at southern and northern parts of narthex. They were there either because it was a church with side aisles, or because these sections were added to a single naved building.

Entrance from the narthex to the nave was possible by means of an opening with a two-columned door, of which column bases were found in situ. In front of this door, there was a floor mosaic with geometrical patterns and dedicatory inscription in Latin. It was dated to the first half of the $4^{\text {th }}$ century. In later years of excavation, there is no mention about this mosaic, and hence it could be taken that it has't been preserved.

This church is located outside the city walls at the moment. The city walls were built in the $4^{\text {th }}$ century and constantly repaired until the $6^{\text {th }}$ century A.D. [31, pp. 63-65]. Although the church was dated to the $6^{\text {th }}$ century, it was most probably built in the $4^{\text {th }}$, when there were no city walls at all.

In 2012, the first Turkish archaeological excavation in Europe began under my direction. The location was chosen based on a survey and archive work. The excavation site is located approximately in the middle of the city. During the 2012 excavation season, five niches and a baptismal basin in the form of a cross made of reused bricks, were unearthed. In the following year, three more niches were uncovered and an octogonal baptistery was unearthed. The widest point of the baptistery is approximately 13 metres. A long wall in the direction of southnorth was discovered next to the western entrance. Outside this wall, towards the west, a small hypocaust was found. Inside the baptistery, in front of the western entrance, the floor was paved with lime. Approximately two meters away, several large blocks of stone and a water canal were discovered. These were taken as a sign of a pre-baptistery settlement. Probably, there was a Roman house on the same spot. Between southern and northern parts of the baptistery, there is an inclination. The difference in height is 0.4 metre. This is clearly an indication of an earthquake. It could be the one that happened on August $28^{\text {th }}, 358$ A.D., with the epicentre in Nicomedia; the one that destructed large parts of Macedonia [16, pp. 255-259].

Next to the baptistery, there are burials of one female and one male laying in the direction of east-west. Both deceased were in their twenties. According to the carbon 14 tests made by Hungarian Atomic Institute, they were buried in the $5^{\text {th }}-6^{\text {th }}$ century. Despite the ban of burial within and in the vicinity of the baptisteries by the council of Auxerre in 578, it may have been disregarded since it was a local council [19, p. 281]. Since there was one baptistery as a norm in Early Christian period [13, p. 208], our focus shifted to locate the main church of the city. Approximately 5 metres north of baptistery, the two parallel walls in the direction of east-west were discovered. As excavation continued it was clarified that the walls belonged to the main church of the city.

The two-phased church with the dimensions of $20 \times 40$ metres was unearthed (Ill. 18). This was a church in the form of a basilica. There were two side aisles and a nave which ended with a single apse in the east. There was no atrium. The first church, built in the mid $4^{\text {th }}$ century A.D., was destroyed due to an earthquake. Probably at the end of the $4^{\text {th }}$ or beginning of the $5^{\text {th }}$ century, another church was built on the same spot. Basing on this information, a 
probable image of the baptistery and church was made (Ill. 19). The $5^{\text {th }}$ century church was narrowed on the northern and southern sides, approximately 1 metre on each side. During the 2015 excavation season, a very intriguing discovery was made. There were five skeletons laid on the southern wall of the first church. Two of the skeletons, both of which are female, were in better condition. Based on the anthropological analysis made on the spot, it was determined that one of the females was in her twenties, whereas the second one was in her forties. Most probably, these skeletons belong to the people who died in the church during the earthquake and were buried as a sign of respect and privilege.

The entrance to the church is possible by means of the three doors in the west which lead into the narthex. The passage to the nave was possible by means of yet another set of three doors. The central one was the most damaged one. Most probably, it had two-column arrangement. Southern entrance is in better condition. On its floor there is a reused white marble slab. A hole in this slab indicates the position of the door. One metre away on the southern wall, there is another marble slab with a hole which also proves that there was a door there as well.

The nave was separated from the side aisles by columns. Underneath these columns, there were large stone slabs whose traces could still be observed. The nave ends with an apse in the east. The templon before the apse was approximately 0.4 metre high and stood on stone pieces. There are traces of a synthronon of the first church in the apse.

Due to its location, size and its lavish decoration with mosaics, the church we have discovered is the main church of the city. The damage of the $6^{\text {th }}$ century earthquake was disastrous. Its impact can still be seen in the nave. There are holes in the ground deeper than 1 metre. Due to the high cost and difficulties in using the same site for re-erection of the church, a new one was constructed which was most probably the one near northern gates. All the material available was taken from the main church and reused in the new one. No inscription concerning its dedication was ever found. Since it was the main church of the city, it would be safe to assume that it was dedicated to Sts. Florus and Laurus. This church was decorated with floor mosaics discovered in 2013. Except for two birds in the southern nave, all of the mosaics have geometrical patterns. There are also 22 dedicatory inscriptions with names of donors in Latin. The longest inscription is in the middle of the narthex by the main entrance. This inscription survived partially. The term "comes" in inscription is interesting. This word was used as a term of nobility in late antiquity. In the meantime, it meant "the governor and commander of the army". Considering the importance of the army in the area and the fact that there is a military camp in the vicinity, this might have been a dedication to the army commander of the city. Other than this, most of the mosaics are in northern and southern aisles. There are very small fragmentary pieces of mosaics in the nave. The best preserved mosaics were found in the southern end of the narthex. When the second church was under construction, the floor mosaics were laid with mortar in most of the floors except for the area in front of the templon which was paved with bricks. Probably, due to the lack of finance and expertise, the new mosaics were never made and the old ones were never restored. The most important pattern of the mosaics is the cross (Ill. 20). It can be used as an important criterion for dating. Since the depiction of cross on the floor was banned by Theodosius II in 427, it provides terminus post quem [22, I.8.1]. Mosaics with crosses were located mostly in the northern aisle except for a small portion in the southern aisle. 
One of the most important criteria for dating of structures is coins. All the coins found at the site, except for one silver, were made of copper and bronze. The oldest one is from the reign of Geta (209-211 A.D.) and the newest is from the reign of Justin (518-527). Approximately $90 \%$ of the legible coins dated to the $4^{\text {th }}$ century.

Upon excavating Ulpiana between 2012-2015, an Early Christian baptistery and a church were discovered. This was the biggest discovery since the excavations began in 1954. By unearthing these structures a light was shed on regional history and Early Christianity. Great discoveries of early excavations of the 1950s lost some of their spectacular details such as mosaics, original plasters and walls. Heavy handed restoration with the use of concrete in the past caused even more destruction. There was a similar case with the site we have been excavating. The negligence of security and the lack of basic protection against elements caused partial destruction of walls and mosaics. When I was officially invited to Kosovo, my aim was to teach methods of excavation and recording techniques with the help of modern technology. Our part of job has been done and now, hopefully, the local authorities will do their part, namely preservation, conservation and later presentation of the finds. Otherwise, what we have brought out to light will not do any good. In that case, was it really necessary to excavate it?

Title. To Excavate or not? Case of Discovery of an Early Christian Baptistery and Church at Ulpiana, Kosovo.

Author. Halûk Çetinkaya - associate professor. Istanbul Mimar Sinan Fine Arts University, Silahşör cad., 85, Bomonti-Şişli, İstanbul, Turkey. haluk.cetinkaya@msgsu.edu.tr

Abstract: Excavating a site is one of the best methods to obtain information. Our excavation in the ancient city of Ulpiana (Kosovo) is the first and so far the only Turkish excavation in Europe. During this excavation, an Early Christian baptistery and a church with floor mosaics were discovered. Although the discovery of such buildings contributed to studying regional history, there is a concern about the preservation and protection of these monuments. Hence the question arises, by excavating did we do any good or not?

Keywords: Early Christianity; baptistery; church; mosaics; Kosovo; Moesia Superior.

Название статьи. Копать или нет? Случай с открытием раннехристианского баптистерия и церкви в Ульпиане (Косово).

Сведения об авторе. Четинкая Халюк - доцент. Университет изящных искусств имени Мимара Синана, Силахшёр, 85, Стамбул, Турция. haluk.cetinkaya@msgsu.edu.tr

Аннотация. Археологические раскопки - один из методов обретения информации. Наши раскопки в древнем городе Ульпиане, в Косово, - первые и единственные, проводимые на территории Европы турецкой научной организацией. Их результатом стало открытие раннехристианского баптистерия и церкви с напольной мозаикой. Обнаружение подобных зданий, несомненно, вносит вклад в развитие знаний о местной истории. Однако возникают опасения, удастся ли сохранить и защитить эти памятники. Неизбежно встает вопрос: во благо ли раскопки?

Ключевые слова: раннее христианство; баптистерий; церковь; мозаики; Косово; Верхняя Мезия.

\section{References}

1. Berisha M.; Drafehn A.; Gashi S. etc. Archäologisch-geophysikalische Prospektion im Kosovo - Erste Resultate einer bilateralen Forschungskooperation. Archäologischer Anzeiger, 2012, no. 2, pp. 65-92 (in German).

2. Bošković Đ. Rimske ruševine kod Gračanice. Starinar, 1926/1927, no. 4, pp. 269-272 (in Serbian).

3. Čerškov E. Ulpiana Kratak izveštaj o arheološkim istraživanjima u 1959 god. Glasnik Muzeja Kosova $i$ Metohije, 1959-1960, no. 4-5, pp. 371-376 (in Serbian).

4. Čerškov E.; Popović L. Ulpiana. Prethodni izveštaj o arheološkim istraživanjima 1957 god. Glasnik Muzeja Kosova i Metohije, 1957, no. 2, pp. 3-34 (in Serbian). 
5. Çetinkaya H. İstanbul'da Orta Bizans Dini Mimarisi (Middle Byzantine Religious Architecture at Istanbul). Unpublished Ph. D. Dissertation. Istanbul University, 2003 (in Turkish).

6. Croke B. (transl.). The Chronicle of Marcellinus: A Translation and Commentary. Sydney, Australian Association for Byzantine Studies Publ., 1995. 204 p.

7. Cvetković-Tomašević G. Ulpiana, arheološka iskopavanja u središtu i južnom delu antičkog grada. Saopštenja, 1983, no. 15, pp. 67-94 (in Serbian).

8. Delehaye H.; Peeters P.; Coens M. etc. (eds.). Propylaeum ad Acta Sanctorum Decembris: Martyrologium Romanum. Bruxellis, Société de Bollandistes Publ., 1940. 660 p. (in Latin).

9. Dewing H. B.; Downey G. (transl.). Procopius. Buildings, 7. London, W. Heinemann Publ., 1954. 550 p.

10. Dintchev V. Classification of the Late Antique Cities in the Dioceses of Thracia and Dacia. Archaeologia Bulgarica, 1999, no. 3, pp. 39-73.

11. Fidanovski S. Rimska Keramika Ulpijane. Beograd, Centar za arheološka istraživanja Publ., 1990. 71 p. (in Serbian).

12. Fidanovski S. Rimski i ranovizantijski period. Arheološko blago Kosova i Metohije od neolita do ranog srednjeg veka, vol. 1. Belgrade, Gallery of the Serbian Academy of Sciences and Arts Publ., 1998, pp. 258-349 (in Serbian).

13. Fletcher B. A History of Architecture on the Comparative Method for Students, Craftsmen and Amateurs. New York, Charles Scribner's Sons Publ., 1924. 933 p.

14. Gassmann G.; Körlin G. Roman Non-ferrous and Noble Metal Mining in Kosovo. Metalla (Bochum) Sonderheft (International Conference "Archaeometallurgy in Europe III" abstracts), 2011, no. 4, pp. 128129.

15. Gerland E. Corpus Notitiarum Episcopatuum Ecclesia Orientalis Graecae. Die Genesis der Notitia Episcopatuum, vols. 1, 2. Istanbul, Socii Assumptionistae Chalcedonenses Publ., 1931. (in German).

16. Guidoboni E.; Comastri A.; Traina G. Catalogue of Ancient Earthquakes in the Mediterranean Area up to the $10^{\text {th }}$ Century. Bologna - Rome, ING-SGA Publ., 1994. 504 p.

17. Hajdari A.; Kabashi P.; Lamboley J.-L. etc. Premiers résultats des campagnes de fouilles à Ulpiana (20062008). Actes du Ve colloque international de Grenoble (8-11 octobre 2008) sur l'Illyrie méridionale et l'Epire dans l'antiquité, réunis par Jean-Luc Lamboley et Maria Paola Castiglioni, I. Paris, De Boccard Publ., 2011, pp. 449-458 (in French).

18. Hohlova I. L. Ikony Rybinska (Icons of Rybinsk). Rybinsk, Rybinskii dom pechati Publ., 2009. 480 p. (in Russian).

19. Howell L. Synopsis Canonum Ecclesiae Latinae qua Canones Spurii, Epistolae Adulterinae et Decreta Suppositia Istius Ecclesiae Conciliorum in Lucem Proferuntur, et a Veris ac Genuinis Dignoscuntur. Charleston, Nabu Press Publ., 2011. 446 p. (in Latin).

20. Hoxhaj E. Untersuchungen zur geschichte des Kosovo in der Römerzeit. Unpublished Ph. D. Dissertation. University of Vienna, 2000 (in German).

21. Johnson M. J. Parekklesion. The Oxford Dictionary of Byzantium, 2. Oxford, Oxford Unversity Press Publ., 1991, pp. 1587-1588.

22. Krueger P.; Mommsen T. Corpus Iuris Civilis, 1. Berolini, Weidmann Publ., 1872. 1075 p. (in Latin).

23. Majeska G. P. Russian Travelers to Constantinople in the Fourteenth and Fifteenth Centuries. Washington, Harvard University Press Publ., 1984. 486 p.

24. Milich P. Cumulative Slavicity: Cultural Interaction and Language Replacement in the Northern Balkans during the Slavic Migration Period, AD 500-900. Unpublished Ph. D. Dissertation. Ohio State University, 1995.

25. Mirdita Z. Eine Inschrift aus Ulpianum. Zeitschrift für Papyrologie und Epigraphik, 1978, no. 29, pp. 161-166 (in German).

26. Mócsy A. Pannonia and Upper Moesia: A History of the Middle Danube Provinces of the Roman Empire. London - Boston, Routledge and Kegan Paul Publ., 1974. 474 p.

27. Mommsen T. (ed.) Iordanis Romana et Getica. MGH, Auctores Antiquissimi, 5.1. Berolini, Weidmann Publ., 1882. 200 p. (in Latin).

28. Mommsen T.; Hirschfeld O.; Domaszewski A., von. Corpus Inscriptionum Latinorum, 3. Supplementum. Inscriptionum Orientis et Illyrici Latinarum supplementum. Berolini, apud G. Reimerum Publ., 1902. 2038 p. (in Latin).

29. Müllerus C. (ed.) Claudii Ptolemaei geographia, 1. Parisiis, A. Firmin Didot Publ., 1883. 570 p. (in Ancient Greek and Latin). 
30. Papazoglu F. The Central Balkan Tribes in Pre-Roman Times. Triballi, Autariatae, Dardanians, Scordisci and Moesians. Amsterdam, Hakkert Publ., 1978. 664 p.

31. Parović-Pešikan M. Antička Ulpijana prema dosadšnjim istraživanjima. Starinar, 1981, no. 32, pp. 5872 (in Serbian).

32. Petković S. Roman Fibulae from Ulpiana. Starinar, 2003, no. 53-54, pp. 241-253 (in Serbian).

33. Popović V. Trois inscriptions protobyzantines de Bregovina. Starinar, 1989-1990, no. 40-41, pp. 279290 (in French).

34. Popović L.; Čerškov E. Ulpiana. Prethodni izveštaj o arheološkim istraživanjima od 1954 do 1956 god. Glasnik Muzeja Kosova i Metohije, 1958, no. 1, pp. 319-327 (1n Serbian).

35. Szilágyi J. Dardani (Dardania). Der kleine Pauly, 1: Aachen-Dichalkon. Stuttgart, Druckenmüller, 1964, pp. 1386-1387 (in German).

36. Zeiller J. Les origines chrétiennes dans les provinces danubiennes de l'Empire romain. Rome, "L’Erma" di Bretschneider, 1967. 631 p. (in French). 


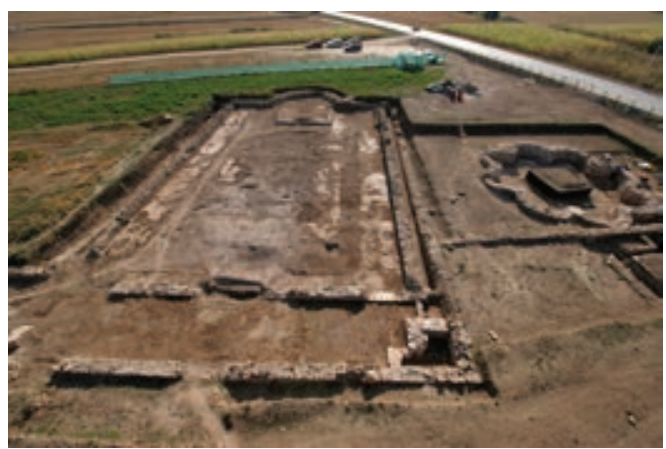

Ill. 18. Aerial photograph of the church. Ulpiana, Kosovo. Photo by H. Çetinkaya

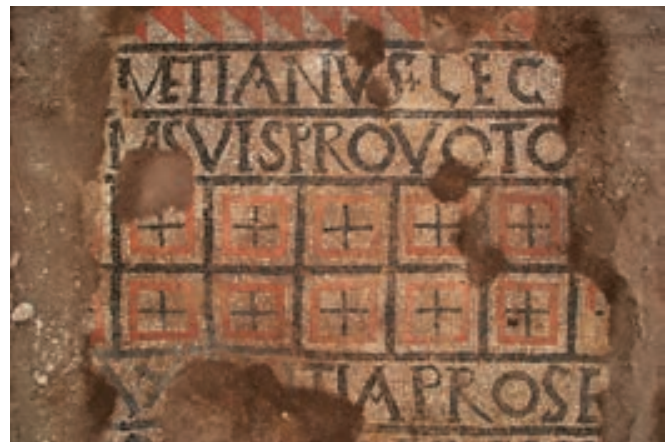

Ill. 20. Mosaics with crosses. Ulpiana, Kosovo. Photo by H. Çetinkaya
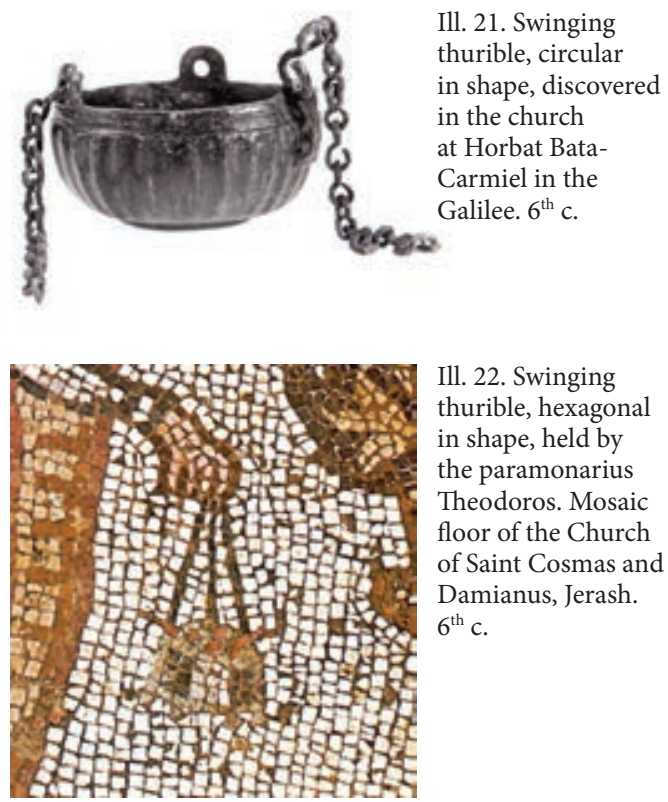

Ill. 22. Swinging thurible, hexagonal in shape, held by the paramonarius Theodoros. Mosaic floor of the Church of Saint Cosmas and Damianus, Jerash. $6^{\text {th }} \mathrm{c}$.

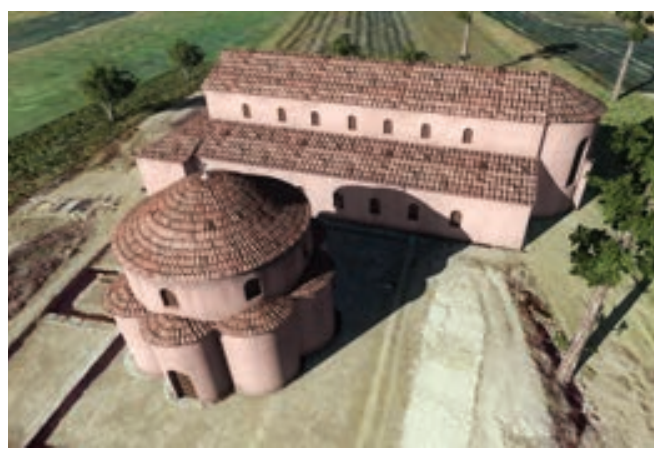

Ill. 19. Probable look of church and baptistery. Ulpiana, Kosovo. Author: T. Öner

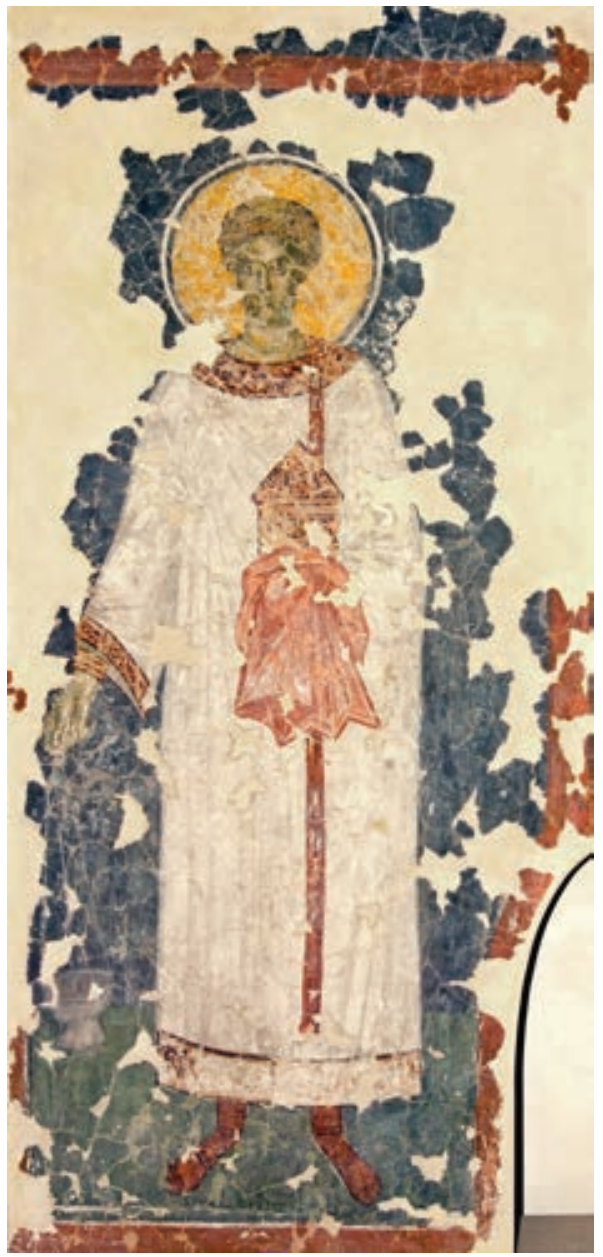

Ill. 23. St. Stephen swinging a thurible without a lid. Wall painting from the Transfiguration Church at Kovalevo. 1380. Novgorod Museum 